Scientia Marina 70 (2)

June 2006, 325-334, Barcelona (Spain)

ISSN: 0214-8358

\title{
Otolith chemical composition as a useful tool for sciaenid stock discrimination in the south-western Atlantic
}

\author{
ALEJANDRA V. VOLPEDO ${ }^{1,2,3}$ and ALICIA FERNÁNDEZ CIRELLI ${ }^{1,2}$ \\ ${ }^{1}$ Centro de Estudios Transdisciplinarios del Agua, FVET, Universidad de Buenos Aires, Av. Chorroarín 280, Ciudad de \\ Buenos Aires (C1427CWO). \\ ${ }^{2}$ Consejo Nacional de Investigaciones Científicas y Técnicas (CONICET). \\ ${ }^{3}$ Departamento de Biodiversidad y Biología Experimental, Facultad de Ciencias Exactas y Naturales, Universidad de \\ Buenos Aires. Facultad de Ciencias Exactas y Naturales, Ciudad Universitaria Pabellón 2, (1428). Buenos Aires \\ Argentina. E-mail: volpedo@bg.fcen.uba.ar
}

SUMMARY: Striped weakfish (Cynoscion guatucupa) and whitemouth croaker (Micropogonias furnieri) are important commercial and recreational species found in abundance along the South American Atlantic coast. In recent years otolith chemical composition has been used as a tool for identifying fish stocks for several species. The chemical composition of $C$. guatucupa and M. furnieri otoliths was determined by inductively coupled plasma-optical emission spectrometry (ICP-OES) in samples from coastal sites (Partido de La Costa, Mar del Plata and San Blás Bay). Significant differences in the ratios of $\mathrm{Mg} / \mathrm{Ca}, \mathrm{Mn} / \mathrm{Ca}$ and $\mathrm{Sr} / \mathrm{Ca}$ for C. guatucupa otoliths and $\mathrm{Cd} / \mathrm{Ca}, \mathrm{Cu} / \mathrm{Ca}, \mathrm{Mg} / \mathrm{Ca}, \mathrm{Sr} / \mathrm{Ca}$ and $\mathrm{Zn} / \mathrm{Ca}$ for M. furnieri otoliths suggest the existence of two different fish stocks, one originating in the north (including Samborombón Bay and Partido de La Costa fisheries) and another originating in the south (including "El Rincón" and San Blás fisheries). These results agree with previous studies on the same species using different methodologies. These stocks may be separated by an oceanographic barrier, the "Frente El Rincón". Otolith chemical composition has not been previously used in South America for identifying fish stocks and may be a simple, quick and useful tool for the sustainable exploitation and management of commercial species.

Keywords: otolith chemical composition, stock discrimination, Cynoscion guatucupa, Micropogonias furnieri.

RESUMEN: LA COMPOSICIÓN QUÍMICA DE LOS OTOLITOS COMO UNA HERRAMIENTA ÚTIL PARA LA DISCRIMINACIÓN DE STOCKS PESQUEROS DE ESCIÉNIDOS EN EL ATLÁNTICO SUDOCCIDENTAL. - La pescadilla de red (Cynoscion guatucupa) y la corvina rubia (Micropogonias furnieri) son especies de importancia comercial y recracional abundantes a lo largo de la costa atlántica sudamericana. En recientes años, la composición química del otolito es utilizada como una herramienta para la identificación de stocks pesqueros. La composición química de los otolitos de $C$. guatucupa y M. furnieri se determino por espectrómetro de emisión atómica (ICP-OES) en muestras provenientes de localidades costeras (Partido de La Costa, Mar del Plata y Bahía San Blás). Se hallaron diferencias significativas en las relaciones $\mathrm{Mg} / \mathrm{Ca}, \mathrm{Mn} / \mathrm{Ca}$ y $\mathrm{Sr} / \mathrm{Ca}$ para $C$. guatucupa y en $\mathrm{Cd} / \mathrm{Ca}$, $\mathrm{Cu} / \mathrm{Ca}, \mathrm{Mg} / \mathrm{Ca}, \mathrm{Sr} / \mathrm{Ca}$ y $\mathrm{Zn} / \mathrm{Ca}$ para M. furnieri, lo que sugiere la existencia de dos diferentes stocks pesqueros, uno originado en el norte (que incluye las pesquerías de Bahía Samborombón y del Partido de La Costa) y otro stock, originado en el sur (que incluye las pesquerías de "El Rincón” y Bahía Blás). Estos resultados coinciden con los hallados en estudios previos utilizando diferentes metodologías. Estos stocks pueden estar separados por un barrera oceanografía el "Frente El Rincón”. La composición química del otolito se utilizo por primera vez en Sudamerica para la identificación de stocks pesqueros, siendo un método fácil, rápido y una herramienta útil para el manejo y explotación sustentable de especies comerciales.

Palabras clave: composición química de los otolitos, discriminación de stocks, Cynoscion guatucupa, Micropogonias furnieri. 


\section{INTRODUCTION}

Striped weakfish (Cynoscion guatucupa, Cuvier, 1830) is distributed from Río de Janeiro, Brazil $\left(22^{\circ} 35^{\prime} \mathrm{S}\right)$ to Argentina $\left(43^{\circ} 00^{\prime} \mathrm{S}\right)$ and whitemouth croaker (Micropogonias furnieri, Desmarest, 1823) is distributed from Veracruz, México $\left(20^{\circ} 20^{\prime} \mathrm{N}\right)$ to southern Buenos Aires province $\left(41^{\circ} 00^{\prime} \mathrm{S}\right)$ (Cousseau and Perrota, 2000).

Striped weakfish and whitemouth croaker are adapted to variable environmental conditions and mainly inhabit estuaries (Jaureguizar et al., 2004; Menni, 2004).

Striped weakfish is predominantly piscivorous (López Cazorla, 1996) and whitemouth croaker is generalist, with benthic invertebrates being the predominant food items (Sánchez et al., 1991).

Both species reproduce in Río de la Plata estuary $\left(34^{\circ} \mathrm{S}, 55^{\circ} \mathrm{W}\right.$ to $\left.36^{\circ} 30^{\prime} \mathrm{S}, 58^{\circ} 30^{\prime} \mathrm{W}\right)$, which includes Samborombón Bay $\left(35^{\circ} 27^{\prime} \mathrm{S}, 56^{\circ} 45^{\prime} \mathrm{W}\right.$ to $36^{\circ} 22^{\prime} \mathrm{S}$; $\left.56^{\circ} 35^{\prime} \mathrm{W}\right)$ and the "El Rincón" area $\left(39^{\circ} \mathrm{S}, 62^{\circ} \mathrm{W}\right.$ to $39^{\circ} 30^{\prime} \mathrm{S}, 60^{\circ} \mathrm{W}$ ) (Cassia and Booman, 1985; Díaz de Astarloa and Bolasina, 1992; Lasta and Acha, 1996; Lasta et al., 1998; Acha et al., 1999; Machi et al., 2003) (Fig. 1).

Juvenile striped weakfish (total length (TL) of $100-320 \mathrm{~mm}$ ) live in shallow coastal waters, whereas adults are associated with mean water column depths (10-25 m) at coastal areas (López Cazorla, 2000). Male and female striped weakfish reach sexual maturity at $320 \mathrm{~mm}$ TL (Cousseau and Perrota, 2000).

Juvenile whitemouth croaker (TL: 120 -300 mm) occupy shallow waters $(<5 \mathrm{~m})$ while adults are associated with soft substrates (Cousseau and Perrotta, 2000; Jaureguizar et al., 2003; Volpedo and Echeverría, 2003). Sexual maturity is reached at 340 $\mathrm{mm}$ TL for males and $360 \mathrm{~mm}$ TL for females, corresponding to 4 and 5 years of age respectively (Cousseau and Perrota, 2000).

Striped weakfish and whitemouth croaker are two major components of the fisheries of the Argentinean, Brazilian and Uruguayan coastal region (Haimovici et al., 1989; Norbis, 1995; Lasta and Acha, 1996). In Argentina, striped weakfish annual catches are approximately 16000 tons, and whitemouth croaker annual catches are in the order of 18000 to 20000 tons (Suquele and Colautti, 2003; SAGPyA, 2004). These commercial coastal species are the most important ones in Argentine fisheries ( $24 \%$ of the total landed catch of coastal commercial

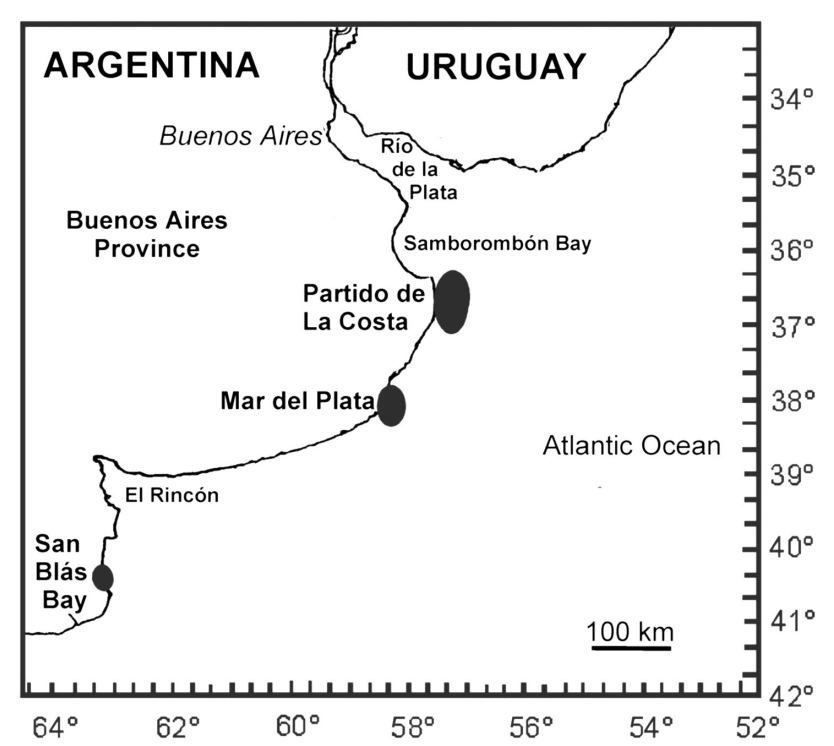

FIG. 1. - Sampling stations near the Buenos Aires coast (Argentina), Partido de La Costa, Mar del Plata and San Blás Bay.

species) and are an important socioeconomic resource for local communities (SAGPyA, 2004).

High concentrations of fish from July to September and the high vulnerability of these species to low net selectivity, pose several difficulties for fisheries management (Ruarte and Aubone, 2004). Furthermore, these species are common fishing resources between Argentina (Río de la Plata estuary) and Uruguay (Lasta et al., 2000) and hence, fish stock species identification is needed for fisheries management.

The numerous definitions of "stock" as applied to fisheries mostly involve defining population(s) of fish that maintain their genetic integrity over time (Booke, 1981). Fish stocks may be identified and discriminated by different methods (e.g. population parameters, capture-mark-recapture studies, physiological and behavioural characters, morphometric and meristic characters, cytogenetic characters and biochemical characters). As all these methods have limitations in their application, alternative approaches are continuously evaluated (Milton and Chenery, 2001). The success of capture-mark-recapture techniques for stock identification purposes is dependent on representative tagging and recapture efforts. These studies are generally expensive and time consuming (Begg and Waldman, 1999). Both physiological and behavioural characteristics (e.g. fecundity at age, spawning time, sexual maturity, growth rate) have frequently been used to discriminate stocks (Begg and Waldman, 1999), but applying 
them requires a knowledge of the fish life history. Phenotypic characteristics do not provide direct evidence of genetic isolation between stocks; however, these can indicate the prolonged separation of postlarval fish in different environmental regimes (Begg et al., 1999). Genetic variation between stocks can provide a direct basis for stock structure, but can prove inadequate in situations where even low levels of larval or adult mixing occur (Begg and Waldman, 1999), and high levels of gene flow between stocks are found (Levy et al., 1998).

Previous studies (Figueroa and Díaz de Astarloa, 1991; Díaz de Astarloa and Bolasina, 1992; Machi et al., 1992; Díaz de Astarloa and Ricci, 1998) in Argentina suggested morphologic and morphometric differences in striped weakfish and whitemouth croaker from the Buenos Aires coastal zones. Díaz de Astarloa and Bolasina (1992) applied morphometric and meristic characters of striped weakfish, suggesting the existence of another group in the "El Rincón" area. The same result was obtained for whitemouth croaker applying morphometric and meristic characters (Figueroa and Díaz de Astarloa, 1991; Díaz de Astarloa and Ricci, 1998).

In recent years, otoliths have been used as a tool for stock identification, along with variation in morphometric and morphologic characteristics (Campana et al., 1995; Griffiths, 1996; Gillanders, 2001). In Argentina, otolith morphology and morphometry has been used to discriminate between different stocks of sciaenids from the coast of Buenos Aires province (Volpedo, 2001).

Otolith chemical composition represents a natural tag or fingerprint that may provide information on natal origin and geographic association (Edmonds et al., 1989; 1991; Kalish, 1990 a; Secor et al., 1991; Thresher et al., 1994, Thresher, 1999; Proctor et al., 1995; Campana et al., 1994; Campana et al., 1995; Campana, 1999). The technique relies on the assumption that certain elements present in the otoliths are related to their physical and chemical environment, and that resorption or alteration of these elements during ontogeny is minimal (Campana, 1999; Campana et al., 2000). This method is increasingly being used to help researchers understand the environmental history of fish movements (Radtke and Shafer, 1992), population structure (Thresher et al., 1994), and identification of spawning estuaries (Milton et al., 1997). It has been used to discriminate between fish stocks of southern hemisphere species (Edmons et al., 1991;
Gunn et al., 1992; Gillanders and Kingsford, 2003; Patterson et al., 2004).

In the present study, otolith chemical composition of striped weakfish and whitemouth croaker was analyzed for catches from three coastal sites to test its use as a stock discriminator. It is the first time that this methodology has been applied in South America and may be an important tool for the sustainable exploitation and management of commercially important fisheries.

\section{MATERIALS AND METHODS}

\section{Study area}

The marine coast of Buenos Aires extends from San Antonio Cape ( $\left.36^{\circ} 21^{\prime} S\right)$, Río de la Plata external limit, to the mouth of the Río Negro $\left(41^{\circ} 12^{`} \mathrm{~S}\right)$. The coastal shelf slopes gently. In summer, coastal waters have a temperature between $15^{\circ} \mathrm{C}$ and $25^{\circ} \mathrm{C}$, while in winter the temperature range is between $10^{\circ} \mathrm{C}$ and $12^{\circ} \mathrm{C}$ (Hoffman et al., 1997) and is influenced by three water masses: subantarctic, subtropical and estuarine masses (Piola and Rivas, 1997). The presence of two coastal ocean fronts, the Subtropical/Subantartic front and the "Frente El Rincón" (Acha et al., 2004), results from the confluence of continental and marine waters, and the tidal effect (Guerrero and Piola, 1997). The oceanic fronts have important biological characteristics, where high biodiversity and biomass production are observed (Lasta and Acha, 1996; Olson, 2002; Acha et al., 2004).

The coastal sites within the study area (Partido de La Costa, Mar del Plata and San Blás Bay) have different geomorphological and environmental characteristics (Fig 1). Partido de La Costa $\left(36^{\circ} 12^{\prime} \mathrm{S}\right.$ to $36^{\circ} 43^{\prime} \mathrm{S}, 57^{\circ} 45^{\prime} \mathrm{W}$ to $57^{\circ} 40^{\prime} \mathrm{W}$ ) is constituted by a group of 11 small towns, whose main activity is tourism in summer (four months) due to the presence of extensive, gently sloping coasts. Surface area: ca. $3000 \mathrm{~km}^{2}$, spring-summer temperature: $20^{\circ} \mathrm{C}-22^{\circ} \mathrm{C}$ and spring-summer salinity: $20-30$ (CEADO, 2004).

Mar del Plata $\left(38^{\circ} 00^{\prime} \mathrm{S}, 57^{\circ} 33^{\prime} \mathrm{W}\right)$ is an important coastal city $(598,500$ inhabitants; INDEC 2001$)$ where industrial activities (fishing, textiles) and tourism (in summer the population may increase by 500,000 inhabitants) take place. Surface area: ca. $1500 \mathrm{~km}^{2}$, spring-summer temperature: $17^{\circ} \mathrm{C}-20^{\circ} \mathrm{C}$ 
and spring-summer salinity: 32.2-33.8 (CEADO, 2004).

San Blás Bay $\left(40^{\circ} 14^{\prime} \mathrm{S}, 62^{\circ} 14^{\prime} \mathrm{W}\right)$ is located at Jabalí Island. Tide channels, marshes, sand beaches and dunes are found along the coast. San Blás Bay is perhaps the only place along the Argentine coast not subject to the pressure of commercial overfishing. This unique environment is one of the most important areas for biodiversity conservation in the Buenos Aires province. It is also a breeding and nursery area for many commercial fish such as Micropogonias furnieri, Cynoscion guatucupa, Netuma barbus (Lacépède, 1803) and sharks (Notorhynchus sp., Mustelus smitti (Springer, 1939), and Callorhynchus callorhynchus (Linné, 1758) (Cousseau and Perrotta, 2000). Surface area: ca. $600 \mathrm{~km}^{2}$, spring-summer temperature: $12^{\circ} \mathrm{C}-17^{\circ} \mathrm{C}$ and spring-summer salinity: 33.2->34 (CEADO, 2004).

\section{Sample Collection}

Striped weakfish and whitemouth croaker were collected from sampling stations along the coast of Buenos Aires province, during spring-summer 2002-2003. Striped weakfish $(n=20)$ were captured in Partido de La Costa and San Blás Bay, and whitemouth croaker $(n=48)$ were collected in Partido de La Costa, Mar del Plata and San Blás Bay (Fig.1). Sample sites were selected taking into account their importance for commercial fisheries. These samples are representative of fisheries, based on minimum total lengths of $320 \mathrm{~mm}$ and $340 \mathrm{~mm}$ for striped weakfish and whitemouth croaker respectively.

Fish total length (TL) was measured (mm). Otoliths were removed, cleaned of adhering tissue, weighed (OW) (in g) on an analytical balance (to $0.1 \mathrm{mg}$ ), digested in $10 \%$ nitric acid and rinsed in Milli Q water.

Calcium was determined by titration using EDTA (APHA, 1993). Trace elements were analyzed by inductively coupled plasma-optical emission spectrometry (ICP-OES, Perkin Elmer Optima 2000). Typical operational conditions were as follows: power $(1400 \mathrm{~W})$, nebulizer Ar flow rate $\left(0.5 \mathrm{~mL} \mathrm{~min}^{-1}\right)$, auxiliary Ar flow rate $\left(0.7 \mathrm{~mL} \mathrm{~min}^{-1}\right)$, plasma Ar flow rate $\left(15 \mathrm{~mL} \mathrm{~min}^{-1}\right)$ and sample nebulizer flow $\left(1.2 \mathrm{~mL} \mathrm{~min}^{-1}\right)$. The method Multicomponent Spectral Fitting (MSF) was applied to improve the sensibility and the detection limit (Nölte, 1999). Internal standards of Ytrio 371.029 $\left(1 \mathrm{mg} \mathrm{L}^{-1}\right)$ were used to correct matrix interference in the ICP-OES. The wavelengths used for the determinations were: $\mathrm{Cd}(226.502$ and 228.801), $\mathrm{Cu}$ (324.752), $\mathrm{Mg}$ (285.210 and 279.075), $\mathrm{Mn}$ (257.610), Sr (232.235) and Zn (213.857). The standard reference materials (SRM) MERCK were used for calibration. Verification and analytic methods validation were performed with the SMR Fish Otolith (No. 22) from NIES (National Institute for Environmental Studies). Detection limits, which were calculated from the concentration of analyte yielding a signal equivalent to three times the standard deviation of the blank signal, were $0.3 \mu \mathrm{g} / \mathrm{g}$ (Cd); $0.36 \mu \mathrm{g} / \mathrm{g}(\mathrm{Cu}) ; 0.24 \mu \mathrm{g} / \mathrm{g}(\mathrm{Mg}) ; 0.02 \mu \mathrm{g} / \mathrm{g}$ $(\mathrm{Mn}) ; 0.12 \mu \mathrm{g} / \mathrm{g}(\mathrm{Sr})$ and $0.24 \mu \mathrm{g} / \mathrm{g}(\mathrm{Zn})$ respectively. Blank samples were prepared in the same manner, but no otolith was present. Determinations were performed in triplicate with a relative error of $<1.0 \%$ for all of them. The Element:Ca ratios (micromoles $/ \mathrm{mol}$ ) were calculated.

\section{Statistical analyses}

The mean values of the Element:Ca ratios for each site were compared using analysis of variance (ANOVA) (Sokal and Rholf, 1995) and multiple comparisons test Tuckey's Honestly significant differences (HSD) among sites (Zar, 1999); $\mathrm{P}<0.05$ was considered statistically significant. Otolith weight (OW) was included as a covariate. Normality and homogeneity of variance assumptions of ANOVA were tested by the Kolmogorov-Smirnov test and the Levene statistic respectively $(\mathrm{P}<0.05)$. The $\mathrm{Cd} / \mathrm{Ca}$ and $\mathrm{Cu} / \mathrm{Ca}$ were logarithmic transformed to normalize the variances (Sokal and Rholf, 1995; Zar, 1999). The Element:Ca ratio of each sciaenid species in Partido de La Costa and San Blás Bay were compared using ANOVA. The software used in statistical analysis was Statistica 5.1 (Statsoft $\AA$, 1999).

Multi-elemental compositions were analyzed by non-parametric analysis of similarity (ANOSIM) permutations test (Clarke, 1993). Triangular dissimilarity matrices were calculated using Euclidean dissimilarity measures on double square root transformed data. The ANOSIM permutations test was used to assess the significance of differences among estuaries. A global R-value (=test statistic) was obtained based on average dissimilarities within replicate samples and average dissimilarities between different samples. The global R-value was tested by evaluating random rearrangements (permutations) of the data (Clarke, 1993); in this case, the procedure was repeat- 
TABLE 1. - Sampling data for fish collected during the study. n: sample size, TL: mean total length \pm standard deviation, OW: otolith weight.

\begin{tabular}{|c|c|c|c|c|c|c|c|c|c|c|}
\hline \multirow[b]{2}{*}{ Species } & \multirow[t]{2}{*}{ Coastal Sites } & \multicolumn{3}{|c|}{ Partido de La Costa } & \multicolumn{3}{|c|}{ Mar del Plata } & \multicolumn{3}{|c|}{ San Blás Bay } \\
\hline & & $\mathrm{n}$ & Mean \pm SD & Range & $\mathrm{n}$ & Mean \pm SD & Range & $\mathrm{n}$ & Mean $\pm \mathrm{SD} \quad \dot{\mathrm{R}}$ & Range \\
\hline $\begin{array}{l}\text { Striped } \\
\text { weakfish }\end{array}$ & $\begin{array}{l}\text { TL }(\mathrm{mm}) \\
\text { OW (g) }\end{array}$ & 10 & $\begin{array}{l}435 \pm 19.58 \\
3.05 \pm 0.92\end{array}$ & $\begin{array}{c}390-460 \\
1.87-4.96\end{array}$ & & & & 10 & $\begin{array}{l}468 \pm 14.75 \\
4.80 \pm 1.25\end{array}$ & $\begin{array}{c}440-490 \\
3.22-6.69\end{array}$ \\
\hline $\begin{array}{l}\text { Whitemouth } \\
\text { croaker }\end{array}$ & $\begin{array}{l}\text { TL }(\mathrm{mm}) \\
\text { OW (g) }\end{array}$ & 6 & $\begin{array}{c}504.83 \pm 50.87 \\
3.30 \pm 0.71\end{array}$ & $\begin{array}{c}420-570 \\
2.33-4.37\end{array}$ & 11 & $\begin{array}{c}511 \pm 99.58 \\
3.7 \pm 1.66\end{array}$ & $\begin{array}{c}400-700 \\
2.00-6.62\end{array}$ & 31 & $\begin{array}{c}636.77 \pm 108.14 \\
6.18 \pm 2.73\end{array}$ & $\begin{array}{ll}4 & 400-800 \\
& 1.53-11.52\end{array}$ \\
\hline
\end{tabular}

ed 5000 times. Multiple comparisons of individual pairs were also carried out in the same way. All analyses were performed using PRIMER programs (Clarke and Warwich, 1994).

Non-metric multidimensional scaling (nMDS) plots were used as the ordination method. The dissimilarity matrix was calculated using Euclidean distances. The goodness of fit of the data points in the nMDS was measured by the stress coefficient, where stress tends to zero when data are perfectly represented (Clarke, 1993). The final nMDS explains the absence of axis scales and labels in the
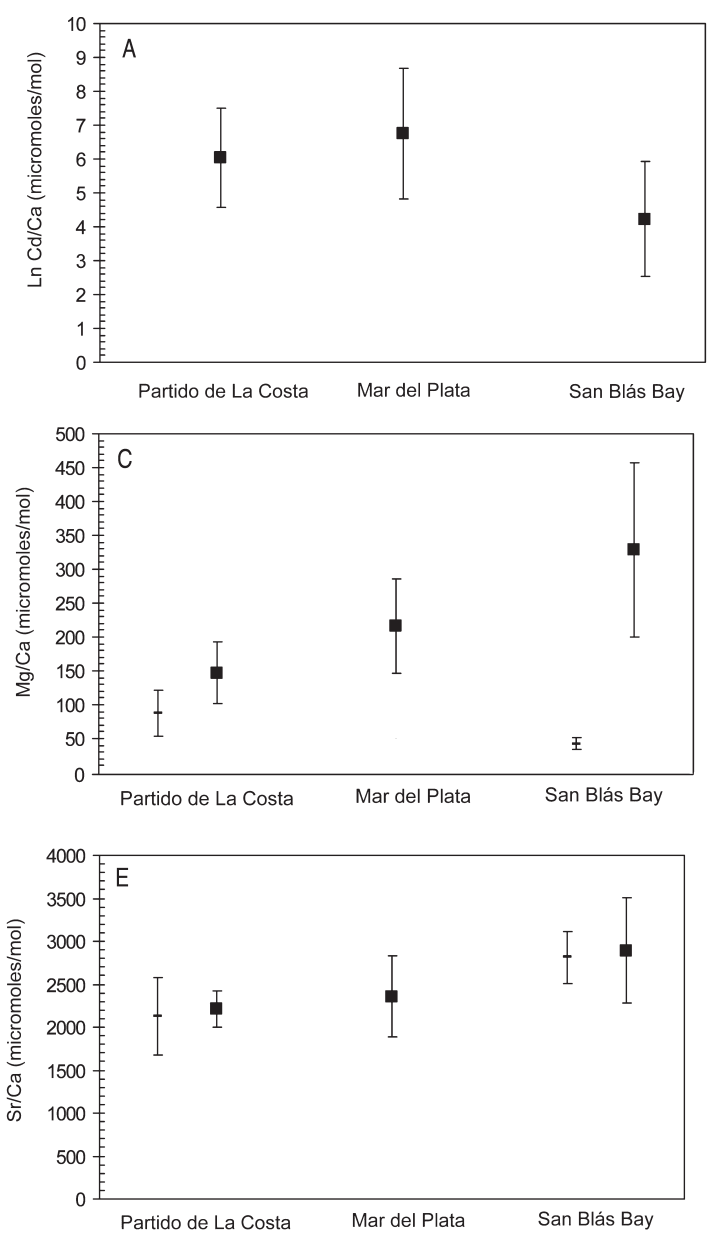
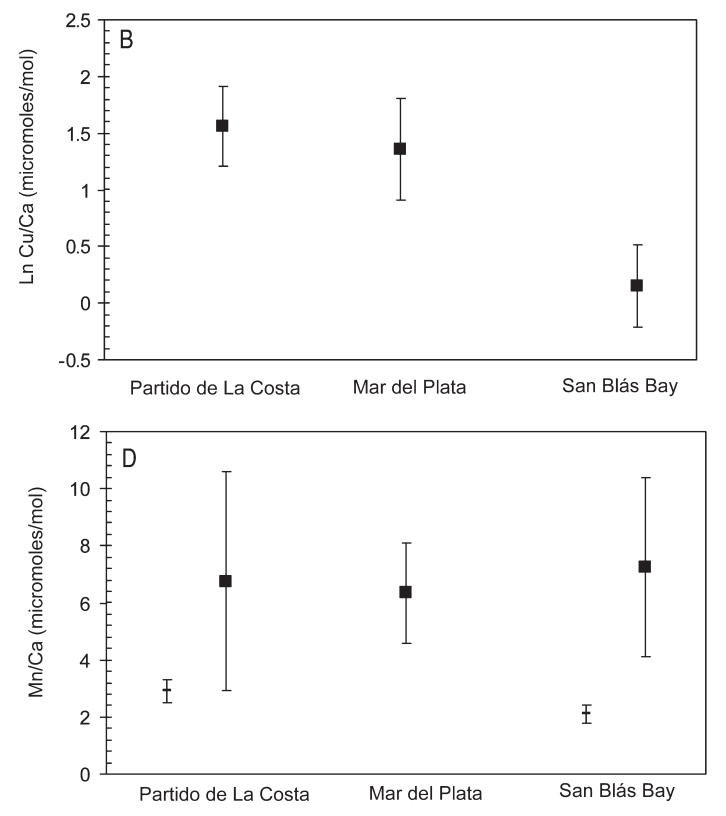

figures (Clarke, 1993). Data was pooled by species for comparing coastal sites.

\section{RESULTS}

Fish total length and otolith weight of striped weakfish and whitemouth croaker are shown in Table 1. Otolith chemical analysis showed that four elements ( $\mathrm{Mn}, \mathrm{Mg}, \mathrm{Sr}$ and $\mathrm{Zn}$ ) were detectable in otoliths from striped weakfish and six elements $(\mathrm{Cd}$, $\mathrm{Cu}, \mathrm{Mn}, \mathrm{Mg}, \mathrm{Sr}$ and $\mathrm{Zn}$ ) were detectable in otoliths

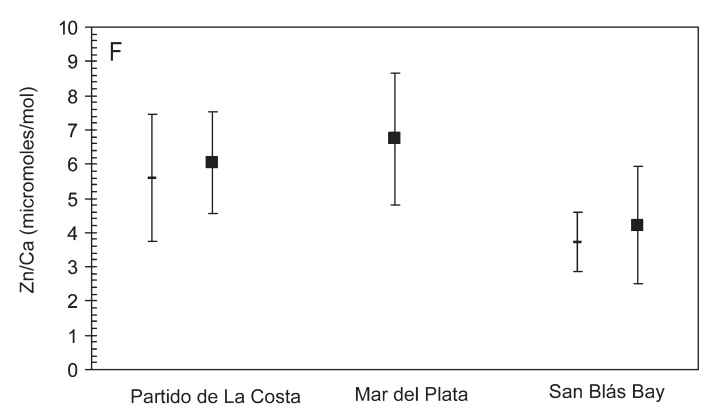

FIG. 2. - Element/Ca ratios for striped weakfish (-) and whitemouth croaker ( $\square$ ) from sample sites. (Mean \pm SD). 
TABLE 2. - Element:Ca ratios for striped weakfish and whitemouth croaker for each coastal site. SD: standard deviation.

\begin{tabular}{|c|c|c|c|c|c|c|c|c|}
\hline & \multicolumn{2}{|c|}{ Partido de La Costa } & \multicolumn{2}{|c|}{ Mar del Plata } & \multicolumn{2}{|c|}{ San Blás Bay } & \multicolumn{2}{|l|}{ ANOVA } \\
\hline & Mean \pm SD & Range & Mean \pm SD & Range & Mean \pm SD & Range & F & $\mathrm{P}$ \\
\hline \multicolumn{9}{|c|}{ Striped weakfish } \\
\hline $\mathrm{Mg} / \mathrm{Ca}$ & $86.87 \pm 33.85$ & $60.63-162.59$ & & & $41.57 \pm 8.23$ & $32.58-57.96$ & $F_{(1: 20)}=5.577$ & $<0.05$ \\
\hline $\mathrm{Mn} / \mathrm{Ca}$ & $2.91 \pm 0.41$ & $2.33-3.68$ & & & $2.10 \pm 0.31$ & $1.73-2.71$ & $\mathrm{~F}^{(1 ; 20)}=6.147$ & $<0.05$ \\
\hline $\mathrm{Sr} / \mathrm{Ca}$ & $2129 \pm 450$ & $1752-2601$ & & & $2812 \pm 300$ & $2457-3316$ & $F_{(1,19)}=15.994$ & $<0.01$ \\
\hline $\mathrm{Zn} / \mathrm{Ca}$ & $5.88 \pm 1.85$ & $1.87-8.29$ & & & $3.71 \pm 0.87$ & $2.33-5.09$ & $\mathrm{~F}_{(1 ; 18)}=1.009$ & 0.33 \\
\hline \multicolumn{9}{|c|}{ Whitemouth croaker } \\
\hline $\mathrm{Cd} / \mathrm{Ca}^{1}$ & $0.22 \pm 0.12$ & $0.10-0.39$ & $0.17 \pm 0.08$ & $0.07-0.33$ & $0.02 \pm 0.01$ & $0.007-0.045$ & $F_{0.48}=65.606$ & $<0.01$ \\
\hline $\mathrm{Cu} / \mathrm{Ca}^{1}$ & $5.01 \pm 1.62$ & $2.77-7.09$ & $4.26 \pm 1.92$ & $2.12-7.67$ & $1.24 \pm 0.52$ & $0.54-3.03$ & $\mathrm{~F}^{(2 ; 4)}=38.235$ & $<0.01$ \\
\hline $\mathrm{Mg} / \mathrm{Ca}$ & $147.07 \pm 45.2$ & $100.76-213.69$ & $216.48 \pm 70.24$ & 138.66-348.09 & $327.9 \pm 128.40$ & $120.09-651.10$ & $\mathrm{~F}_{(2 ; 4)}^{(2 ; 4)}=7.907$ & $<0.01$ \\
\hline $\mathrm{Mn} / \mathrm{Ca}$ & $6.75 \pm 3.84$ & $3.93-13.92$ & $6.35 \pm 1.77$ & $4.18-9.96$ & $7.25 \pm 3.14$ & $3.47-15.92$ & $\mathrm{~F}_{(2.45)}^{(2.44)}=2.256$ & 0.117 \\
\hline $\mathrm{Sr} / \mathrm{Ca}$ & $2214 \pm 211$ & $1982-2464$ & $2296 \pm 380$ & $1670-2779$ & $2878 \pm 612$ & $2111-3621$ & $\mathrm{~F}_{(2 ; 45)}^{(2,48)}=4.061$ & $<0.05$ \\
\hline $\mathrm{Zn} / \mathrm{Ca}$ & $6.04 \pm 1.46$ & $4.19-8.23$ & $6.74 \pm 1.94$ & $3.38-10.10$ & $4.22 \pm 1.69$ & $1.93-7.96$ & $\mathrm{~F}_{(2 ; 47)}^{(2 ; 48)}=3.223$ & $<0.05$ \\
\hline
\end{tabular}

from whitemouth croaker. These elements were chosen for the analyses.

Element:Ca ratios for striped weakfish from Partido de La Costa and San Blás Bay and Element:Ca ratio for whitemouth croaker from Partido de La Costa, Mar del Plata and San Blás Bay are presented in Figure 2.

The ANOVA results for striped weakfish showed significant differences in $\mathrm{Mg} / \mathrm{Ca}, \mathrm{Mn} / \mathrm{Ca}$ and $\mathrm{Sr} / \mathrm{Ca}$ ratios between coastal sites, while no significant differences were observed for $\mathrm{Zn} / \mathrm{Ca}$ (Table 2).

Significant differences among the sampling sites were observed for $\mathrm{Cd} / \mathrm{Ca}, \mathrm{Cu} / \mathrm{Ca}, \mathrm{Mg} / \mathrm{Ca}, \mathrm{Sr} / \mathrm{Ca}$ and $\mathrm{Zn} / \mathrm{Ca}$ ratios of whitemouth croaker otoliths, while the $\mathrm{Mn} / \mathrm{Ca}$ ratio showed no significant differences (Table 2).

The multiple comparison test Tuckey's Honestly significant differences (HSD) applied to $\ln \mathrm{Cd} / \mathrm{Ca}$, $\ln \mathrm{Cu} / \mathrm{Ca}, \mathrm{Mg} / \mathrm{Ca}, \mathrm{Sr} / \mathrm{Ca}$ and $\mathrm{Zn} / \mathrm{Ca}$ showed significant differences $(\mathrm{P}<0.05)$ in the whitemouth croaker otolith chemical composition between San Blás Bay and the other coastal locations. However, no significant differences were observed in whitemouth croaker otolith chemical composition between Partido de La Costa and Mar del Plata (ln Cd/Ca: $\mathrm{P}=$ 0.382; $\operatorname{ln~} \mathrm{Cu} / \mathrm{Ca}: \mathrm{P}=0.495 ; \mathrm{Mg} / \mathrm{Ca}: \mathrm{P}=0.45$; $\mathrm{Sr} / \mathrm{Ca}$ : $\mathrm{P}=0.867$ and $\mathrm{Zn} / \mathrm{Ca}: \mathrm{P}=0.643$ ).

The multivariate composition of trace elements was analyzed. Significant differences were found between all coastal sites for the chemical composition of striped weakfish otoliths (ANOSIM, global$\mathrm{R}=0.636, \mathrm{P}<0.001)$. However, pairwise comparisons of sample sites for ANOSIM suggest that Partido de La Costa samples differ from San Blás Bay. The nMDS plot showed that in striped weakfish, the otolith samples could be grouped in Partido de La
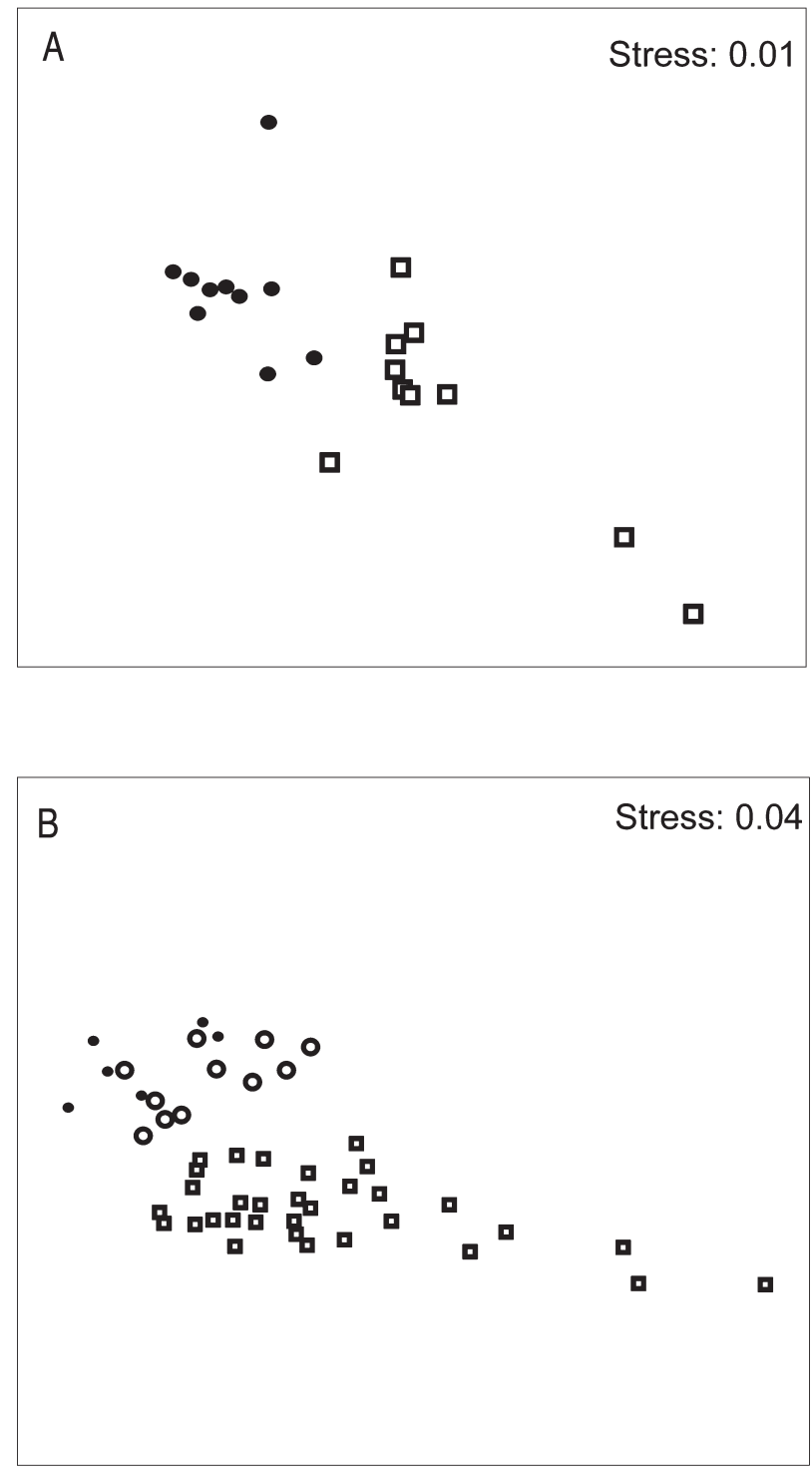

FIG. 3. - nMDS ordinations of multi-element composition for (a) striped weakfish (b) whitemouth croaker collected at coastal sites.( Partido de La Costa, (○) Mar del Plata and (๖) San Blás Bay. 
TABLE 3. - Results of ANOVA of Element: Ca ratios for striped weakfish and whitemouth croaker of Partido de La Costa and San Blás Bay.

\begin{tabular}{llll}
\hline & Partido de La Costa & San Blás Bay \\
\hline $\mathrm{Mg} / \mathrm{Ca}$ & $\mathrm{F}_{(1 ; 16)}=8.217, \quad \mathrm{P}<0.05$ & $\mathrm{~F}_{(1 ; 38)}=53.022, \mathrm{P}<0.01$ \\
$\mathrm{Mn} / \mathrm{Ca}$ & $\mathrm{F}_{(1 ; 15)}=10.134, \quad \mathrm{P}<0.01$ & $\mathrm{~F}_{(1 ; 40)}=31.89, \quad \mathrm{P}<0.01$ \\
$\mathrm{Sr} / \mathrm{Ca}$ & $\mathrm{F}_{(1 ; 1)}=1.551, \quad \mathrm{P}=0.23$ & $\mathrm{~F}_{(1 ; 37)}=3.52, \quad \mathrm{P}=0.68$ \\
$\mathrm{Zn} / \mathrm{Ca}$ & $\mathrm{F}_{(1 ; 12)}=1.721, \quad \mathrm{P}=0.21$ & $\mathrm{~F}_{(1 ; 3)}=3.40, \quad \mathrm{P}=0.07$ \\
\hline
\end{tabular}

Costa and in San Blás Bay, based on chemical composition (Fig. 3A).

Significant differences were found between all coastal sites for chemical otolith composition of whitemouth croaker (ANOSIM, global-R=0.301, $\mathrm{P}<0.001)$. However, pairwise comparisons of sample sites for ANOSIM suggest that Partido de La Costa did not differ from Mar del Plata, whereas both of them differed from San Blás Bay. The nMDS plot showed that in whitemouth croaker the samples could be grouped into two sets based on otolith chemical composition, one related to Partido de La Costa and Mar del Plata, and the other one to San Blás Bay (Fig. 3B).

These results suggest the existence of two different fish stocks for striped weakfish and whitemouth croaker.

The otolith chemical composition of the sciaenid species was different in each coastal site. In Partido de La Costa and San Blás Bay, the sciaenid species presented significant differences in the ratios of $\mathrm{Mg} / \mathrm{Ca}$ and $\mathrm{Mn} / \mathrm{Ca}$, whereas the $\mathrm{Sr} / \mathrm{Ca}$ and $\mathrm{Zn} / \mathrm{Ca}$ ratios showed no differences (Table 3, Figs. 2C, F).

\section{DISCUSSION}

The otolith chemical composition of striped weakfish and whitemouth croaker showed significant differences between coastal sites. In other studies, differences in otolith composition among different geographic areas were also found (Campana et al., 1995; Gillanders and Kingsford, 2000, 2003). These differences are frequently used to discriminate between fish stocks.

Significant differences in $\mathrm{Mg} / \mathrm{Ca}, \mathrm{Mn} / \mathrm{Ca}$ and $\mathrm{Sr} / \mathrm{Ca}$ ratios in the otoliths of striped weakfish in the coastal province of Buenos Aires suggest the existence of two stocks, one originating in the North (Partido de La Costa) and the other in the South (San Blás Bay).

Significant differences in the ratios of $\mathrm{Cd} / \mathrm{Ca}$, $\mathrm{Cu} / \mathrm{Ca}, \mathrm{Mg} / \mathrm{Ca}, \mathrm{Sr} / \mathrm{Ca}$ and $\mathrm{Zn} / \mathrm{Ca}$ in the otoliths from whitemouth croaker from the 3 sampling stations suggest that the fish may have occupied different environments during their lives. Differences in element concentration among fish from different stations are not due to size differences, because in the ANOVA test otolith weight was the covariate. These facts let us to discriminate between different fish stocks: one originating in the north (Partido de La Costa and Mar del Plata area) and another originating in the south (San Blás Bay). The northern stock is probably constituted not only from fish from Partido de La Costa and Mar del Plata, but also those from Samborombón Bay, based on their geographical proximity and previous reports (Figueroa and Díaz de Astarloa, 1991; Díaz de Astarloa and Bolasina, 1992; Díaz de Astarloa and Ricci, 1998; Volpedo, 2001). On the other hand, the southern stock is probably constituted from fish species from San Blás Bay and those from the "El Rincón" area.

The existence of two separate fish stocks of striped weakfish and whitemouth croaker may be explained by the occurrence of an oceanographic event. Along the South American Atlantic coast other studies of the discrimination of sciaenids stocks have been carried out (Paiva Filho and Cergole, 1988; Isaac, 1988; Vazzoler and Phan, 1989; Vazzoler, 1991). Some of these studies suggest that the differentiation of stocks of these species, may be due to upwelling in Cabo Frio, Brazil $\left(23^{\circ} \mathrm{S}\right)$, which could function as an oceanographic barrier, facilitating diversification processes (Paiva Filho and Cergole, 1988; Isaac, 1988). It is possible that in Argentina, the two different fish stocks of striped weakfish and whitemouth croaker may be separated by another oceanographic barrier, the "Frente El Rincón" (39॰-39³0' S) (Fig. 1).

The "Frente El Rincón" was characterized by Piola and Rivas (1997), Guerrero and Piola, (1997) and Acha et al. (2004), as an area whose water mass characteristics (temperature, salinity, density) differ to those of the rest of Buenos Aires province coastal waters. The coastal regime in the "El Rincón" front is characterized by vertical homogeneity due to tidal forcing, and this coastal front is separated from the coast by diluted coastal waters from the Negro and Colorado rivers $\left(960 \mathrm{~m}^{3} \mathrm{~s}^{-1}\right.$ total average discharge), and from shelf waters (Acha et al., 2004). The salinity gradient increases due to the presence of high saline waters originating in San Matías Gulf. The front encloses an area of $10000 \mathrm{~km}^{2}$, and has weak seasonality (Acha et al., 2004). 
The chemical composition of the otolith is the result of the accretion of trace elements during the fish's life cycle. Otolith chemical composition variability depends on different factors associated with physicochemical water characteristics and with the fish itself (ecology, physiology, diet, microhabitat uses and others). Thus otolith chemical composition may vary throughout the different stages in the fish life history, or when environmental changes occur (Gillanders and Kingsford, 2000). Changes in water chemistry may be due to continuous oceanographical events, environmental pressure associated with the El Niño Southern Oscillation (ENSO) or freshwater inputs in coastal zones.

In summary, significant differences in $\mathrm{Cd}, \mathrm{Cu}$, $\mathrm{Mg}$ and $\mathrm{Mn}$ otolith concentrations were observed between striped weakfish and whitemouth croaker. These interspecific variations in otolith chemical composition may be explained by trophic level, use of microhabitats, the species' behaviour, or the depth and the residence time in the coastal area of the two sciaenids species (Kalish, 1990b; Sadovy and Severin, 1992; Fowler et al., 1995; Kinsgford and Gillanders, 2000; Sánchez Jerez et al., 2002).

Further studies, including expanded sampling along the Buenos Aires coast in order to determine the variability among sites and sampling over a number of years, to determine temporal variability in otolith composition are in progress.

Otolith chemical composition allowed us to identify two different stocks of striped weakfish and whitemouth croaker in the Buenos Aires coastal zone. Commercial exploitation of striped weakfish and whitemouth croaker, which accounts for up to $24 \%$ of the total landed catch of coastal commercial species, should be managed differently in the future, where fishery efforts should be regulated in relation to each fish stock.

This technique has not been previously used in Argentina and may constitute a simple, quick and useful tool for studying fish stocks of commercially significant species.

\section{ACKNOWLEDGEMENTS}

We are grateful to the Universidad de Buenos Aires and to the Consejo Nacional de Investigaciones Científicas y Técnicas (CONICET) for financial support.

\section{REFERENCES}

Acha, E.M., H. Miazan, C.A. Lasta and R.A. Guerrero. - 1999. Estuarine spawning of the whitemouth croaker Micropogonias furnieri (Pisces: Sciaenidae) in the Río de la Plata, Argentina. Mar. Freshwater. Res., 50: 57-65.

Acha, E.M., H. Miazan, C.A. Lasta, R.A. Guerrero, M. Favero and J. Bava. - 2004. Marine fronts at the continental shelves of austral South America. Physical and ecological processes. J. Mar. Syst., 44: 83-105.

APHA. - 1993. Standard methods for the examination of water and wastes. American Public Health Association. Washington. D.C.

Begg, G. A., K.D. Friedland and J.B. Pearce. - 1999. Stock identification and its role in stock assessment and fisheries management: an overview. Fish. Res., 43: 1-8.

Begg, G.A. and J.R. Waldman. - 1999. An holist approach to fish stock identification. Fish. Res., 43: 35-44.

Booke, H.E. - 1981. The conundrum of the stock concept-are nature and nurture definable in fisheries science? Can J. Fish. Aquat. Sci., 38: 1495-1480.

Campana, S.E. - 1999. Chemistry and composition of fish otolith: pathway, mechanism and applications. Mar. Ecol. Prog. Ser., 188: 263-297.

Campana, S.E., A.J. Fowler and C.M. Jones. - 1994. Otolith elemental fingerprinting for sock determination of Atlantic cod (Gadus morhua) using laser ablation ICPMS. Can J. Fish. Aquat. Sci., 51: 1942-1950.

Campana, S.E., J.A. Gagne and J.W. McLoren. - 1995. Elemental fingerprinting of fish otolith using ICPMS. Mar. Ecol. Prog. Ser., 122: 115-120.

Campana, S.E., G.A. Chouinard, J.M. Hanson, A Fréche and J. Brattey. - 2000. Otolith elemental fingerprints as biological tracers of fish stocks. Fish. Res., 46: 343-357.

Cassia, M.C. and C.I. Booman. - 1985. Distribución del ictioplancton en el Mar Argentino en los años 1981-1982. Physis Secc. A, 43(105): 91-111.

CEADO (Centro Argentino de Datos Oceanográficos). - 2004. Datos físico químicos Atlántico SW. Available online af http://www.hidro.gov.ar

Clarke, K.R. - 1993. Non-parametric multivariate analyses of changes in community structure. Aust. J. Ecol., 18: 117-143.

Clarke, K.R. and R.M. Warwich. - 1994. Change in Marine Communities: an approach to statistical analysis and interpretation. Plymouth: Natural Environment Research Council.

Cousseau, M.B. and R.G. Perrotta. - 2000. Peces Marinos de Argentina. Biología, distribución, pesca. INIDEP. Buenos Aires, Argentina.

Díaz de Astarloa, J.M. and S.N. Bolasina. - 1992. Análisis estadístico de los caracteres morfométricos y merísticos de la pescadilla de red (Cynoscion striatus) en el área comprendida entre $34^{\circ}$ y $39^{\circ} 30^{\prime}$ S. Publ. Com. Tec. Mix. Fr. Mar.,11: 57-62.

Díaz de Astarloa, J.M. and L. Ricci. - 1998. Meristic comparison of the whitemouth croaker, Micropogonias furnieri (Demarest, 1823) (Piscis: Sciaenidae) in southwestern Atlantic between $34^{\circ} 30^{\prime}$ and $39^{\circ} 30^{\prime}$ 'S. Rev. Biol. Mar. Oceanogr., 33 (2): 213-222.

Edmonds, J.S., M.J. Moran, N. Caputi and M. Morita. - 1989. Trace element analysis of fish sagittae as an aid to stock identification: pink snapper (Chrysophrys auratus) in Western Australia waters. Can. J. Fish Aquat. Sci., 46: 50 -54.

Edmonds, J.S., N. Caputi and M. Morita. - 1991. Stock discriminations by trace elements analysis of otoliths of orange roughy (Hoplostethus atlanticus) a deep water marine teleost. Aust. J. Mar. Freshw. Res., 42: 383 - 389.

Figueroa, D.E. and J.M. Díaz de Astarloa. - 1991. Análisis de los caracteres morfométricos y merísticos de la corvina rubia (Micropogonias furnieri) entre los $33^{\circ} \mathrm{S}$ y $40^{\circ} \mathrm{S}$ (Pisces, Sciaenidae). Atlântica, Río Grande, 13: 75-86.

Fowler, A.J., S.E. Campana, C.M. Jones and S.R. Thorrold. - 1995. Experimental assessment of the effect of temperature and salinity on elemental composition of otolith using solution-based ICPMS. Can. J. Fish. Aquat. Sci., 52: 1421-1430.

Gillanders, B.M. - 2001. Trace metals in four structures of fish and their use for estimates of stock structure. Fish. Bull., 99: 410-419.

Gillanders, B.M and M.J. Kingsford. - 2000. Elemental fingerprints of otoliths of fish may distinguish estuarine 'nursery' habitats. Mar. Ecol. Prog. Ser., 201: 273-286. 
Gillanders, B.M. and M.J. Kingsford. - 2003. Spatial variation in elemental composition of otoliths of three species of fish (Family Sparidae). Estuar. Coast. Shelf Sci., 57: 1049-1064.

Griffiths, M.H. - 1996. Age and growth of South African silver cob Argyrosomus inodorus (Sciaenidae), with evidence for separate stocks. S. Afr. J. Mar. Sci., 17: 37- 48.

Guerrero, R.A. and A.R. Piola. - 1997. Masas de agua en la plataforma continental. In: E. Boschi (ed). El Mar Argentino y sus recursos pesqueros: Antecedentes históricos de las exploraciones en el mar y características ambientales 1, pp. 107118. Instituto Nacional de Investigación y Desarrollo Pesquero. Mar del Plata, Buenos Aires, Argentina.

Gunn, J.S., I.R. Harrowfid, C.H. Proctor and R.E. Threser. - 1992. Electron probe microanalysis of fish otoliths-evaluation of techniques for studying age and stock discrimination. J. Exp. Mar. Biol. Ecol., 158: 1-36.

Haimovici, M., S.D. Pereira and P.C. Viera. - 1989. La pesca demersal en el sur de Brasil en el periodo 1975-1985. Publ. Com. Téc. Mix. Fr. Mar., 5: 151-161.

Hoffman, J.A.J., M.N. Núñez and M.C. Piccolo. - 1997 Características climáticas del océano Atlántico Sudoccidental. In: E. Boschi (ed). El Mar Argentino y sus recursos pesqueros: Antecedentes históricos de las exploraciones en el mar y características ambientales 1, pp. 163-193. Instituto Nacional de Investigación y Desarrollo Pesquero. Mar del Plata, Buenos Aires, Argentina.

INDEC (Instituto Nacional de Encuestas). - 2001. Censo Nacional de Hogares y Viviendas 2001. (Available online at $\mathrm{http} / / \mathrm{www}$.indec.gov.ar)

Isaac, V.J. - 1988. Synopsis of biological data on the whitemouth croaker Micropogonias furnieri (Demarest, 1823). FAO Fish. Synop., 150: 1-35.

Jaureguizar, A., J. Bava, C.R. Carozza and C.A. Lasta. - 2003. Distribution of whitemouth croaker Micropogonias furnieri in relation to environmental factors at the Río de la Plata estuary, South America. Mar. Ecol. Prog. Ser., 255: 271-282.

Jaureguizar, A.J., R.C. Menni, R.Guerrero and C.A. Lasta. - 2004. Environmental factors structuring fish communities of the Río de la Plata estuary. Fish. Res., 66: 195-211.

Kalish, J.M. - 1990a. Use of otolith microchemistry to distinguish the progeny of sympatric anadromous and non-anadromous salmonids. Fish. Bull., 88: 657- 666.

Kalish, J.M. - 1990b. Otolith microchemistry: validation of the effects of physiology, age and environment on otolith composition. J. exp. Mar. Biol. Ecol., 132: 151-178.

Kingsford, M.J. and B.M. Gillanders. - 2000. Variation in concentrations of trace elements in otoliths and eye lenses of a temperature reef fish, Parma microlepis, as a function of depth, spatial scale and age. Mar. Biol., 137: 403-414.

Lasta, C.A. and E.M Acha. - 1996. Cabo San Antonio: su importancia en el patrón reproductivo de peces marinos. Publ. Com. Téc. Mix. Fr. Mar., 16: 39-45.

Lasta, C., M. Acha, G. Machi, R. Guerrero and H. Miazán. - 1998. Identificación de un área de desove multiespecífica en la zona de El Rincón. Propuesta para el establecimiento de una zona de veda. Inf. Tec. Interno INIDEP, 102: 1-5.

Lasta C., C. Carroza, P. Suquele, C. Bremec, E. Errazti, R. Perrotta, C. Bértelo and J. Bocanfusso. - 2000. Característica y dinámica de la explotación de corvina rubia (Micropogonias furnieri) durante la zafra invernal. Años 1995 y 1997. Inf. Tec. Interno INIDEP, 36: 1-141.

Levy, J.A., R. Maggioni and M.B. Conceição. - 1998. Close genetic similarity among populations of the white croaker (Microponias furnieri) in the south and south-eastern Brazilian coast. I. Allozyme studies. Fish. Res., 39: 87-94.

López Cazorla, A. - 1996. The food of Cynoscion striatus (Cuvier) (Pisces: Sciaenidae) in Bahía Blanca area, Argentina. Fish. Res., 26: 371-379.

López Cazorla, A. - 2000. Age structure of the population of weakfish Cynoscion guatucupa (Cuvier) in the Bahía Blanca waters, Argentina. Fish. Res., 46: 279-286.

Machi, G.J., A. Aubone and E.H. Christiansen. - 1992. Incidencia de patologías en ovarios de corvina rubia (Micropogonias furnieri) y su relación con distintas zonas costeras de Uruguay y de la Provincia de Buenos Aires. Atlántica, Río Grande, 14: $73-85$.

Machi, G.J., E.M. Acha and M.J. Militelli. - 2003. Seasonal egg production of whitemouth croaker (Micropogonias furnieri) in the Río de la Plata estuary, Argentina-Uruguay. Fish. Bull., 101: 332-342

Menni, R.C. - 2004. Peces y ambientes en la Argentina continental. Monogr. Mus. Argentino Cienc. Nat., 5: 1-316.

Milton, D.A., S.R. Chenery, M.J. Farmer and S.J.M. Blaber. - 1997. Identifying the spawning estuaries of the tropical shad, terubok Tenualosa toli, using otolith microchemistry. Mar. Ecol. Prog. Ser., 153: 283-291.

Milton, D.A. and S.R. Chenery. - 2001. Can otolith chemistry detect the population structure of shad hilsa Tenualosa ilisha? Comparison with the results of genetic and morphological studies. Mar. Ecol. Prog. Ser., 222: 239-251.

Nölte J. - 1999. Minimizing spectral interferences UIT an Array ICP Emission Spectrometer using different strategies for signal evaluation. Atom. Spectrosc., 20: 103-107.

Norbis, W. - 1995. Influence of wind, behaviour and characteristic of the croaker (Micropogonias furnieri) artisanal fishery in the Río de la Plata (Uruguay). Fish. Res., 22: 43-58.

Olson, D.B. - 2002. Biophysical dynamics of ocean fronts. Biological-Physical Interactions in the Sea, pp. 187-218. The Sea, vol. 12. Wiley, New York, USA

Paiva Filho, A.M. and M.C. Cergole. - 1988. Diferenciação geográfica de Nebris microps (Cuvier, 1830), na costa sudeste do Brasil. Bolm. Inst. Oceanogr. Sao Paulo, 36 (1/2): 37-45.

Patterson, M.H., M.J. Kingdford and M.T. McCulloch. - 2004 Elemental signatures of Pomacentrus coelestis otoliths at multiple spatial scales on the Great Barrier Reef, Australia. Mar. Ecol. Prog. Ser., 270: 229-239.

Piola, A.R. and A.L. Rivas. - 1997. Corrientes en la plataforma continental. In: E. Boschi (ed). El Mar Argentino y sus recursos pesqueros: Antecedentes históricos de las exploraciones en el mar y características ambientales 1, pp. 119-132. Instituto Nacional de Investigación y Desarrollo Pesquero. Mar del Plata, Buenos Aires, Argentina.

Proctor, C.H., R.E. Thresher, J.S. Gunn, D.J. Mellis, I.R. Harrowfield and S.H. Sie. - 1995. Stock structure of southern blue fin tuna Thunnus maccoyi an investigation based on probe microanalysis of otolith composition. Mar. Biol., 122: 511-526.

Radtke, R.L. and D.J. Shafer. - 1992. Environmental sensitivity of fish otolith microchemistry. Aust. J. Mar. Freshw. Res., 43: 935-951.

Ruarte, C. and A Aubone. - 2004. La pescadilla de red (Cynoscion guatucupa), análisis de su explotación y sugerencias de manejo para el año 2004. Inf. Tec. Interno INIDEP, 54: 1-165.

Sadovy, Y. and K.P. Severin. - 1992. Trace elements in biogenic aragonite: correlation of body growth rate and strontium levels in the otoliths of white grunt, Haemulon plumieri (Pisces: Haemulidae). Bull. Mar. Sci., 50: 237-257.

SAGPyA (Secretaria de Agricultura, Ganadería, Pesca y Alimentos). - 2004. Estadísticas de Desembarques Pesqueros (Available online at http://www.sagpya.mecon.gov.ar).

Sánchez Jerez, P., B.N. Gillanders and M.J. Kingsford. - 2002. Spatial variability of trace elements in fish otoliths: comparison with dietary items and habitat constituents in seagrass meadows. J. Fish Biol., 61: 801-802.

Sánchez, F., N. Mari, C. Lasta and A. Giangioble. - 1991. Alimentación de la corvina rubia (Micropogonias furnieri) en la Bahía de Samborombón. Publ. Com. Téc. Mix. Fr. Mar. Secc. A, 8: 43-50.

Secor, D.H., A. Henderson-Arzapalo and P.M. Piccoli. - 1991. Can otolith microchemistry chart patterns of migration and habitat utilization in anadromous fishes? J. Exp. Mar. Biol. Ecol., 192, $15-33$.

Sokal, R. R. and F. J. Rohlf. - 1995. Biometry. Third edition. W.H. Freeman and Company, New York.

Suquele, P. and D. Colautti. - 2003. Análisis de los desembarques de la corvina rubia Micropogonias furnieri, en los puertos de zona norte: San Clemente, General Lavalle, Río Salado, Atalaya y Ensenada; entre los años 1999 al 2002. Boletín 1 del Departamento de Explotación Comercial, Dirección de Desarrollo Pesquero, Ministerio de Asuntos Agrarios y Producción, 1-32.

Thresher, R.E. - 1999. Elemental composition of otoliths as a stock delineator in fishes. Fish. Res., 43: 165-204.

Thresher, R.E., C.H. Proctor, J.S. Gunn and I.R. Harrowfield. 1994. An evaluation of electron probe microanalysis of otoliths 
for stock delineation and identification of nursery areas in southern temperature groundfish, Nemadactylus macropterus (Cheilodactylidae). Fish. Bull., 92: 817 - 840.

Vazzoler, A.E.A. De M. - 1991. Sintese de conhecimentos sobre a biología da corvina, Micropogonias furnieri (Demarest, 1823), da costa do Brasil. Atlãntica, Rio Grande, 13: 55-74.

Vazzoler, A.E.A. De M. and V.N. Phan. - 1989. Padrões electroforéticos de proteínas gerais de cristalino de Micropogonias furnieri (Demarest, 1823), da costa sudeste-sul do Brasil: estudo populacional. Bolm. Inst. Oceanogr. São Paulo, 37: 21-28.

Volpedo, A.V. - 2001. Estudio de la morfometría de las sagittae en poblaciones de sciaenidos marinos de aguas cálidas del Perú y aguas templado-frías de Argentina. Ph D Thesis, Univ. Buenos Aires, Argentina.

Volpedo, A.V. and D.D. Echeverría. - 2003. Ecomorphological patterns of the sagitta in fish associated with bottom marine shelf in the Mar Argentino. Fish. Res., 60: 551-560.

Zar, J.H. - 1999. Biostatistical analysis. Fourth edition. Prentice Hall, New Jersey.

Scient. ed.: B. Morales-Nin

Received September 13, 2005. Accepted January 17, 2006. 